\title{
Monitoring of the Leafminer Leucoptera scitella Zell (Lepidoptera: Lyonetidae) by Pheromene Traps in Bulgaria
}

\author{
H. KOUTINKOVA ${ }^{1}$, R. ANDREEV ${ }^{2}$, M. SUBCHEV ${ }^{3}$, M. TÓTH and G. SZŐCS ${ }^{4}$ \\ ${ }^{1}$ Fruit-Growing Institute, Plovdiv, 4004 Plovdiv, Ostromila 12, Bulgaria \\ ${ }^{2}$ Higher Agricultural Institute, Plovdiv, 4000 Plovdiv, 12 Mendeleev, St., Bulgaria \\ ${ }^{3}$ Institute of Zoology, Bulgarian Academy of Sciences, 1000 Sofia, Blvd. Tzar Osvoboditel 1, Bulgaria \\ ${ }^{4}$ Plant Protection Institute, Hungarian Academy of Sciences, H-1525 Budapest, P.O. Box 102, Hungary
}

\begin{abstract}
Three-years monitoring (1996-1998) of the leafminer moth Leucoptera scitella Zell was organized in the apple orchard of the Fruit-Growing Institute, Plovdiv, Bulgaria. Sex pheromone traps with Hungarian caps (Plant Protection Institute, Hungarian Academy of Sciences) were used for first time in this country. As a result, three full generation of the pests were established in all three years and a partial one in 1996 and 1998. The beginning and the end of the first generation were also well defined by the catches in the pheromone traps. However, an overlap of the second and the third on the one hand and the third and the fourth on the other, was observed in all three years. The time of the first catches from the first generation varied from April 9 to April 22. The second and third generation began in the second decade of June and second decade of July, respectively. Chemical treatments seem to have no significant effect on the catches in the pheromone traps.
\end{abstract}

Key words: Pheromone traps, Leucoptera scitella, leafminer.

Leucoptera scitella Zell is an important pest in orchards in Europe and Asia (Balázs, 1993). In Bulgaria is causes serious damages and usually chemical control needs (Ivanov, 1970; Ivanov et al., 1982).

The main sex pheromone component of L. scitella was identified as 5,9-dimethylheptadecane and the attractant activity of the enantiomer mixture of this compound was proved in field by Francke et al. (1987). Later, behavioural activity was found only for the S,S enantiomer of 5,9-dimethylheptadecane and no activity was proved for the other 3 possible enantiomers (Tóth et al., 1989).

The synthetic pheromone was successfully used for monitoring the seasonal flight of $L$. scitella in Italy (Capizzi et al., 1988). Here we present the first trials for monitoring the pest by means of pheromone traps in Bulgaria.

\section{Materials and Methods}

The monitoring of $L$. scitella was carried out in the experimental apple orchard (0.4 ha) of the Fruit-Growing Institute (FGI) in Plovdiv in 1996-1998. The main sorts of apples were Red and Gold Delicious. Because of a heavy infestation of L. scitella and some other leafminer moths, treatments with chitin inhibitors and organophosphate insecticides were conducted in all three years regularly. 
For preparing baits, $300 \mu \mathrm{g}$ of 5,9-dimethylheptadecane were applied onto pieces of red rubber tube as a hexane solution. The baits were used in home-made triangular sticky traps of transparent PVC foil.

Three pheromone traps were installed in the first decade of April in 1996 and 1997 and, because of the warm weather, on March 25 in 1998. The traps were visited each day until the first catches were found and then 3 times a week. The pheromone baits were renewed every 4-6 weeks while the sticky layers were changed regularly depending on the catches.

The meteorological data were obtained on the spot from the Meteorological Station of FGI.

\section{Results and Discussion}

The beginning of the flight of L. scitella in 1996 and 1997 was detected as early as April 22 and April 23, respectively, and in 1998 on April 9 (Figs 1, 2 and 3). The main reason for such an early flight of the pest in the latter case was the unusual warm weather at the end of March and beginning of April in 1998 when the mean daily temperatures reached $16{ }^{\circ} \mathrm{C}$. In all three years the flight of the first generation of $L$. scitella lasted till the end of May with one peak in the first decade of the same month in 1996 and 1997 and two peaks in 1998. The drastic decrease of the moth catches at the end of April 1998 correlates well with the temperature drop down to almost $10{ }^{\circ} \mathrm{C}$. On the whole the first generation as detected by pheromone traps was well separated by the second one in all three years.

Our results correlate well with results obtained in Bulgaria earlier by means of a classic method - large cases isolating whole trees. In four years' investigations (1964-1967), Ivanov (1970) found that the first moth of L. scitella of the overwintered generation appeared in April, varying from April 9 to April 22. Capizzi et al. (1988) have found that in three of four sites monitored by means of pheromone traps in Northern Italy, the flight of the pest began in middle or end of April.

In 1996 and 1997, and less clear in 1988, the flight of the second generation of L. scitella began at the beginning of the second decade of June, and the peak appeared in the middle of the third decade of the same month in all three years. The end of the flight of this generation is more or less fixed to the middle of July.

Ivanov (1970) stated that the second (first summer) generation of L. scitella began between June 17 and June 23 for 1964-1967. Judging by a figure presented in Capizzi et al. (1988), the flight of the second generation of the species in Italy began a little bit later than in Bulgaria, in the third decade of June.

In all three years the flight of the third generation more or less overlapped with the end of the second one and began in the second decade of July. In 1996 and 1997 the end of this generation was quite well defined to the third decade of August, while in 1988 it overlapped considerably with the fourth one. The drastic decrease of the flight at the end of the first decade of August in 1996 that resulted in appearing of two peaks, corre- 

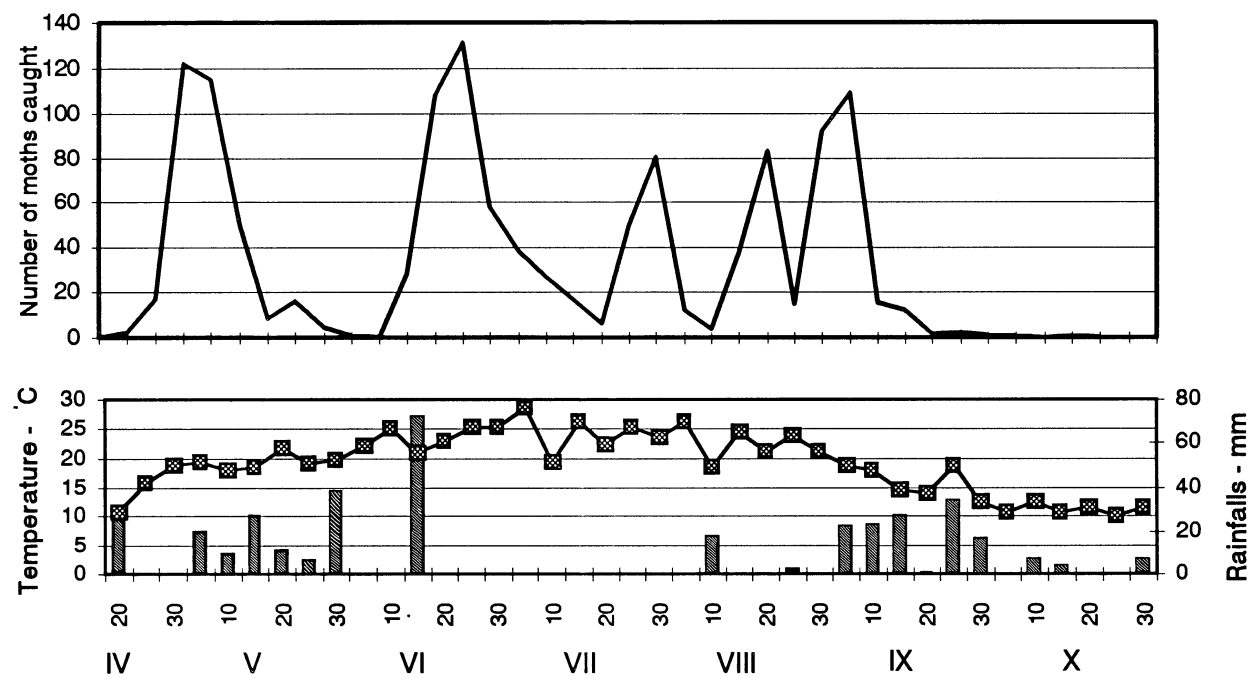

Rainfalls $\rightarrow$ Average temperature

Fig. 1. Seasonal flight of L. scitella in 1996

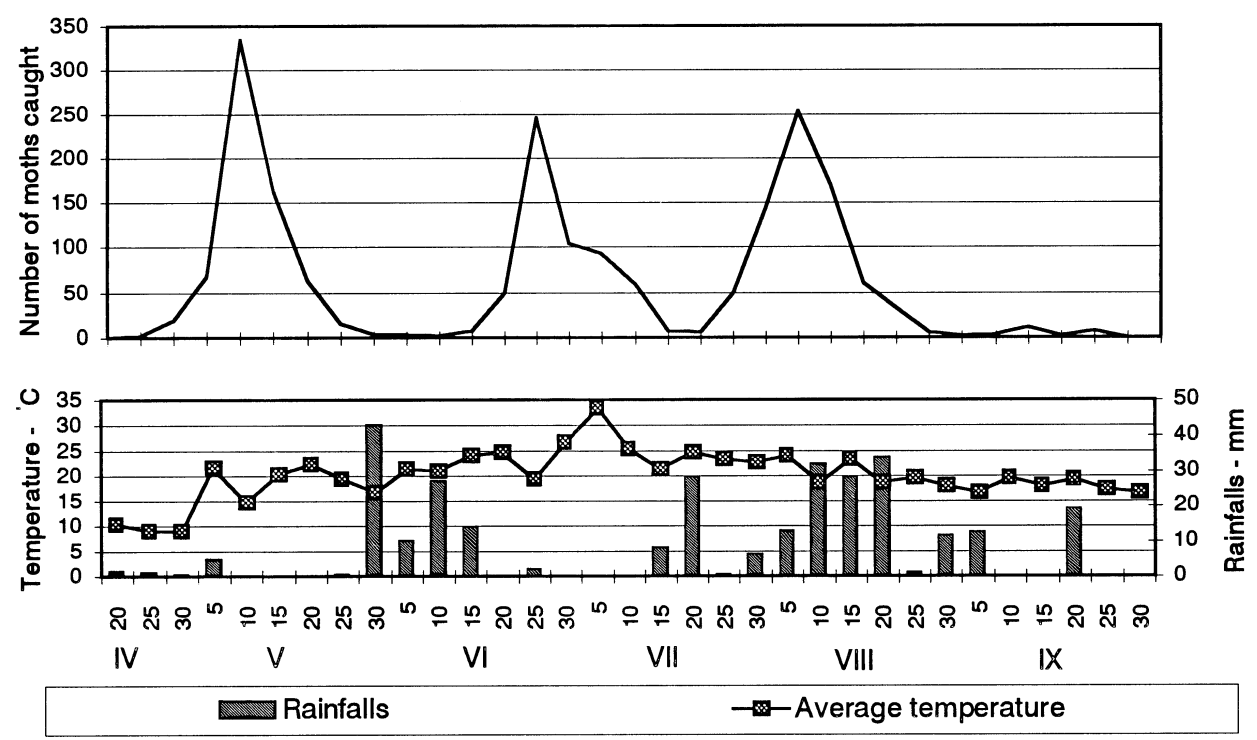

Fig. 2. Seasonal flight of L. scitella in 1997 


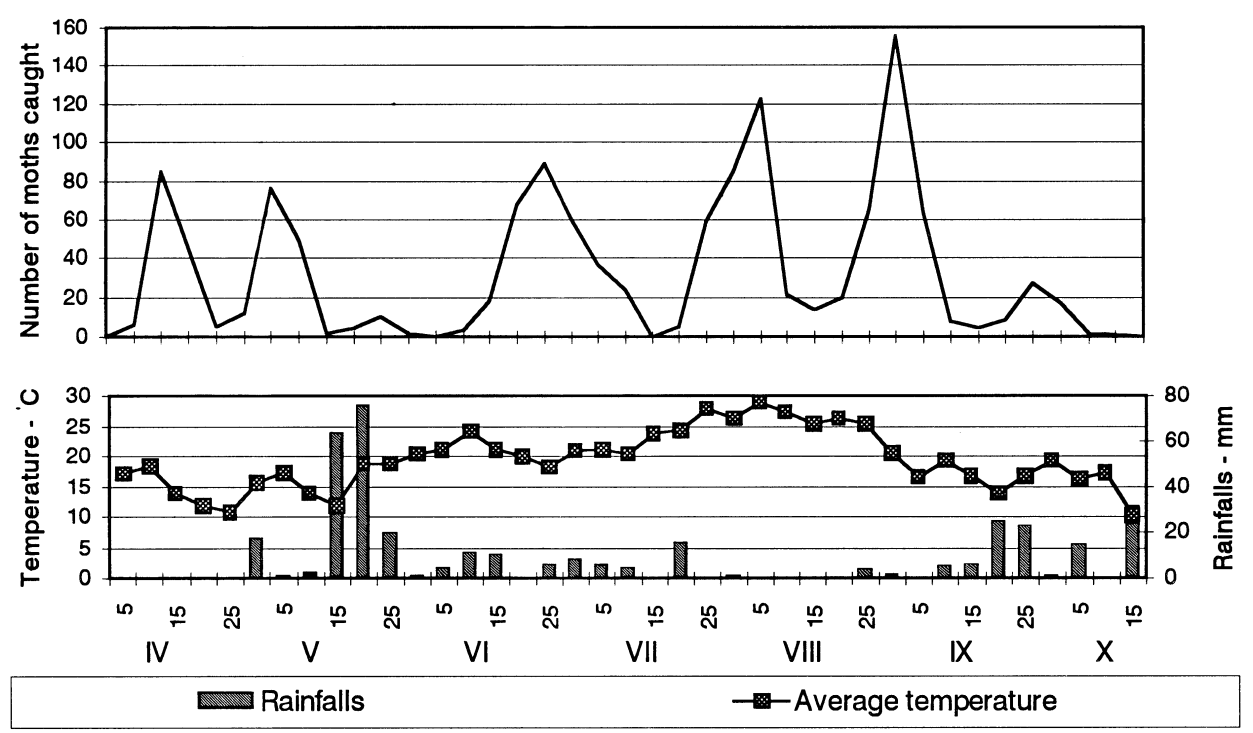

Fig. 3. Seasonal flight of L. scitella in 1998

lates with a drop in the temperatures and a heavy rainfalls at that time.

Only in 1996 and 1998, a fourth generation was well detected by catches in the pheromone traps. However a well expressed flight in 1998 lasted till the beginning of October while in 1996 only to the middle of September. Again this could be explained by the meteorological conditions - in 1988 there was an early decrease of the temperatures and rainfalls in September that caused the decrease of the flight, followed by somewhat warmer period. On the contrary, the steady decreasing in the temperatures in the third decade of September 1996 down to about $10^{\circ} \mathrm{C}$ could explain the steady cease of the flight.

Our results corroborate Ivanov's (1970) finding that L. scitella has three full generations per year and, in some years, a fourth one.

The chemical treatments seem rather not to influence the flight and the catches in pheromone traps. For example after treatments applied on May 7, June 16 and July 25, 1997, the catches either increased following the normal increase of emergence (May, June), or remained at the same level (July). This confirms data of Capizzi et al. (1988) who found that insecticide treatments did not affect significantly catches of L. scitella in pheromone traps.

\section{Acknowledgement}

This study was financially supported by the Bulgarian National Foundation "Scientific Investigation", grant CC-707/1997. 


\section{Literature}

Balázs, K. (1993): Fehérszárnyú molyok - Leucopterigidae Vol. 4/A p. 87-94. In: Jermy, T. and Balázs, K. (eds): A növényvédelmi állattan kézikönyve. Akadémiai Kiadó, Budapest, pp. 447.

Capizzi, A., Rama, F., Reggiori, F. (1988): Il feromone di Leucoptera malifoliella (O. G. Costa): Prime esperienze in Italia. In: Atti XV Congr. naz. ital. ent., L’Aquila, 1988, pp. 957-964.

Francke, W., Franke, S., Tóth, M., Szőcs, G., Guerin, P., Arn, H. (1987): Identification of 5,9-dimethylheptadecane as a sex pheromone of the moth Leucoptera scitella. Naturwissenschaften 74, 143-144.

Ivanov, S. (1970): Leaf miner Chemistoma scitella Z. - biology and tools for control. In: Plant Protection in service of the agriculture. Sofia, Acad. Agricult. Sci., pp. 117-131. (in Bulgarian)

Ivanov, S., Vulkov, G., Dimova, M. (1982): Integrated pest management in orchards. Sofia, NAPS, pp. 1-68. (in Bulgarian)

Tóth, M., Helmchen, G., Leikauf, N., Sziráki, Gy., Szőcs, G. (1989): Behavioural activity of optical isomers of 5,9-dimethylheptadecane, the sex pheromone of Leucoptera scitella L. (Lepidoptera: Lyonetidae). J. Chem. Ecol. 15, 1535-1543. 